\title{
MORPHOLOGICAL STATUS OF EIGHT-YEAR-OLD GIRLS OF VARYING DEGREES OF NUTRITIONAL STATUS
}

\author{
Marija, M. Đorđević $c^{1}$ and Bojan, J. Mitrovic ${ }^{2}$
}

\begin{abstract}
Nutritional status of children is one of the most important indicators of health, mental and physical capabilities and potential for normal and healthy growth and development. The aim of this study was to determine differences in morphological characteristics in eight-year-old girls with varying degrees of nutritional status. The research was conducted on a sample of 91 second grade students of elementary schools in Niš, aged $8.06( \pm 0.02)$. Based on the BMI, three sub-samples were formed (normal weight, overweight and obese subjects). Morphological status was determined by measuring the parameters of longitudinal, transversal and circular dimensionality, body weight and subcutaneous fatty tissue. Differences in morphological variables were determined by using MANOVA/ANOVA and LSD Post Hoc test. The results indicate that, in regards to the BMI, there are significant differences in morphological characteristics in eightyear-old girls. The highest values were observed in obese, then overweight, while the value for at least had a normal weight girls.
\end{abstract}

Key words: differences, elementary school, girls, morphological characteristic, girls, nutritional status.

\section{INTRODUCTION}

The term morphological characteristics of anthropological status implies a system of basic anthropometric latent dimensions (Malacko, 1991). Identification of the latent dimensions in this area was achieved by applying factorial mathematical and statistical methods, through which we managed to isolate anthropometrical factors, that belong to a series of manifest variables (anthropometric measures that can be directly measured) defined as latent

\footnotetext{
${ }^{1}$ mdjordjevic@vaspks.edu.rs, Preschool Teacher Training College, Kruševac

2 bokimitrovic976@gmail.com, Department for Police Education and Trainning, Ministry of Interior of the Republic of Serbia, Belgrade
} 
morphological dimensions. By using factorial approach in morphological area, we identified four main factors which have provided initial information on the structure of morphological dimensions, as well as on some of the hierarchical relationships within that structure. Morphological structure is consisted of longitudinal skeletal dimenzionality, transversal skeletal dimensionality, weight and body volume and subcutaneous fatty tissue. Relative to the age and sex, these factors are sometimes connected as to form two general factors: skeletal dimensions (longitudinal and transversal) and body voluminosity (body volume and subcutaneous fatty tissue). Information about the structure of morphological status is very important in terms of their transformation (growth and development). Morphological characteristics are mainly influenced by genetic and environmental factors. Endogenous influence is not the same in all morphological dimensions. Congenital coefficient for the inherent skeletal dimensionality is .98 , body volume .90 , and .50 for fatty tissue.

Prepubescent age is a very sensitive developmental period. The attention of scientific community is being focused on the physical characteristics of children, pointing out to a worrying prevalence of overweight and obese children. In children and adolescents obesity is defined as increase in body weight above referent values for a given age, sex, and height (Peco-Antić, 2009). The occurrence of obesity during childhood and adolescence increases the possibility of obesity in adulthood. It was found that obesity in girls in 30\%, and among boys in $10 \%$ of cases occurs later in adulthood (Goran, 2001).

Nutritional status of children is one of the most important indicators of health, psychophysical capabilities and the potential for normal and healthy growth and development (Lobstein, Baur, \& Uauy, 2004). Any significant deviation from the optimal weight in children raises the risk for the emergence and development of many non infectious diseases during their lifetime.

The aim of this study was to determine differences in morphological characteristics in eight-year-old girls of different nutritional status.

\section{METHODS}

The sample of participants

The research was conducted on a sample of 91 second grade students of elementary schools in Niš, aged $8.06( \pm 0.02)$. All the subjects were healthy on the testing day and had written consents from their parents and the school principal. Measuring and testing took place in school facilities during the physical education class.

After measuring body height and body weight and calculating the BMI, three sub-samples were formed, according to children's BMI in consistency with the work of Cole, Bellizzi, Flegal, \& Dietz (2000). The first sub-sample consisted of 53 normal weight subjects with an average BMI of $16.00( \pm 1.69)$. The second sub-sample consisted of 29 overweight subjects with an average BMI of $19.40( \pm 0.66)$. The third sub-sample consisted of 9 obese subjects with an average BMI of 24.37 ( \pm 1.62$)$. 
Measuring instruments

Morphological status is determined by measuring the parameters of: longitudinal dimensionality (body height, arm length, leg length), transversal dimensionality (shoulder width, hip width, pelvic width), circular dimensionality and body weight (thorax volume, upper armvolume, thigh volume, calf volume) and subcutaneous fatty tissue (triceps skin folds, sub-scapular skin folds, abdominal skin folds, thigh skin folds, medial calf skin folds). The measuring technique for the morphological characteristics followed the guidelines of the methodology recommended by the International Biological Program (Weiner \& Lourie, 1969).

\section{The statistical analysis}

For all the measuring parameters, meanarithmetic values and standard deviations were calculated. Differences between the groups in morphological and motor variables were determined by using MANOVA/ANOVA and LSD Post Hoc test. The results were analyzed with the Statistical Package for the Social Science (SPSS) version 18.0.

\section{Results}

Table 1 shows basic parameters of descriptive statistics of morphological variables in normal weight, overweight and of obese subjects.

Table 1. Basic descriptive statistical parameters

\begin{tabular}{|l|cc|cc|cr|}
\hline & \multicolumn{2}{c}{ Normal weight } & \multicolumn{2}{c|}{ Owerweight } & \multicolumn{2}{c|}{ Obese } \\
\hline & Mean & SD & Mean & SD & Mean & SD \\
\hline Body height & 133.12 & 6.80 & 133.93 & 5.57 & 141.19 & 4.87 \\
Leg length & 74.29 & 4.49 & 73.85 & 4.54 & 79.82 & 3.67 \\
Arm length & 55.83 & 3.32 & 56.09 & 3.36 & 59.94 & 2.61 \\
Shoulder width & 28.77 & 2.02 & 29.67 & 1.53 & 32.20 & 1.31 \\
Pelvic width & 20.60 & 1.40 & 21.86 & 1.26 & 25.54 & 3.08 \\
Hip width & 22.25 & 1.39 & 23.77 & 1.49 & 26.03 & 1.41 \\
Body weight & 28.50 & 4.60 & 34.87 & 3.38 & 48.67 & 5.10 \\
Thorax volume & 61.10 & 7.05 & 66.99 & 3.75 & 78.53 & 5.06 \\
Upper arm volume & 18.62 & 1.97 & 20.87 & 1.41 & 24.60 & 1.56 \\
Thigh volume & 37.74 & 4.18 & 41.81 & 3.66 & 48.78 & 2.63 \\
Calf volume & 26.94 & 2.23 & 28.91 & 1.79 & 33.60 & 0.97 \\
Triceps skin fold & 11.32 & 3.97 & 14.86 & 3.42 & 20.40 & 3.48 \\
Sub-scapular skin fold & 8.25 & 5.69 & 12.51 & 3.87 & 16.73 & 5.59 \\
Abdominal skin fold & 10.73 & 6.90 & 15.63 & 4.64 & 23.51 & 6.05 \\
Thigh skin fold & 14.09 & 4.76 & 19.19 & 5.04 & 23.16 & 7.35 \\
Medial calf skin fold & 12.66 & 3.88 & 16.14 & 3.18 & 19.64 & 4.22 \\
\hline
\end{tabular}

Legend: Mean - mean value; $S D$ - standard deviation 
Based on these results, it can be concluded that, in comparison to normal and overweight, obese subjects have the highest values in all morphological variables.

Table 2 shows multivariate and univariate analysis of variance in morphological variables between normal weight, overweight and obese subjects. By analysing the results (Table 2) it can be concluded that in the area of morphological abilities, on the multivariate level, there is a statistically significant intergroup difference (.00). The results of univariate analysis of variance (Table 2) indicate that intergroup differences are statistically significant in all the variables of morphological characteristics at a significance level of .01.

Table 2. Multivariate and univariate analysis of variance in morphological characteristics between the groups of different nutritional status

\begin{tabular}{lcc}
\hline & $\mathrm{F}$ & Sig. \\
\hline Body height & 6.41 & $.003^{* *}$ \\
Leg length & 6.75 & $.002^{* *}$ \\
Arm length & 6.16 & $.003^{* *}$ \\
Shoulder width & 14.11 & $.000^{* *}$ \\
Pelvic width & 38.41 & $.000^{* *}$ \\
Hip width & 31.60 & $.000^{* *}$ \\
Body weight & 90.95 & $.000^{* *}$ \\
Thorax volume & 35.43 & $.000^{* *}$ \\
Upper arm volume & 49.76 & $.000^{* *}$ \\
Thigh volume & 34.85 & $.000^{* *}$ \\
Calf volume & 44.76 & $.000^{* *}$ \\
Triceps skin fold & 25.84 & $.000^{* *}$ \\
Sub-scapular skin fold & 13.72 & $.000^{* *}$ \\
Abdominal skin fold & 18.80 & $.000^{* *}$ \\
Thigh skin fold & 17.35 & $.000^{* *}$ \\
Medial calf skin fold & 18.05 & $.000^{* *}$ \\
\hline \multicolumn{1}{c}{ Wilk's $=0.122$} & $\mathrm{~F}=8.48$ & $\mathrm{p}=.000^{* *}$ \\
\hline
\end{tabular}

Legend: Wilk's - Test Wilk's lambdas; F-Pao's F approximation; $p$ (Sig.) -significance level; statistical significance $* * p<.01, * p<.05$ 
Table 3. Intergroup differences in morphological characteristics

\begin{tabular}{|c|c|c|c|c|}
\hline & \multicolumn{2}{|c|}{ GROUPS } & Mean & Sig. \\
\hline \multirow{3}{*}{ Body height } & normal weight & overweight & -.81594 & .575 \\
\hline & normal weight & obese & -8.07379 & $.001 * *$ \\
\hline & overweight & obese & -7.25785 & $.003 * *$ \\
\hline \multirow{3}{*}{ Leg length } & normal weight & overweight & .44418 & .666 \\
\hline & normal weight & obese & -5.52977 & $.001 * *$ \\
\hline & overweight & obese & -5.97395 & $.001 * *$ \\
\hline \multirow{3}{*}{ Arm length } & normal weight & overweight & -.25224 & .740 \\
\hline & normal weight & obese & -4.11048 & $.001 * *$ \\
\hline & overweight & obese & -3.85824 & $.003 * *$ \\
\hline \multirow{3}{*}{ Shoulder width } & normal weight & overweight & -.89915 & $.035^{*}$ \\
\hline & normal weight & obese & -3.43019 & $.000 * *$ \\
\hline & overweight & obese & -2.53103 & $.000 * *$ \\
\hline \multirow{3}{*}{ Pelvic width } & normal weight & overweight & -1.25830 & $.001 * *$ \\
\hline & normal weight & obese & -4.94067 & $.000^{* *}$ \\
\hline & overweight & obese & -3.68238 & $.000 * *$ \\
\hline \multirow{3}{*}{ Hip width } & normal weight & overweight & -1.51080 & $.000 * *$ \\
\hline & normal weight & obese & -3.77862 & $.000 * *$ \\
\hline & overweight & obese & -2.26782 & $.000 * *$ \\
\hline \multirow{3}{*}{ Body weight } & normal weight & overweight & -6.37241 & $.000 * *$ \\
\hline & normal weight & obese & -20.1666 & $.000^{* *}$ \\
\hline & overweight & obese & -13.7942 & $.000^{* *}$ \\
\hline \multirow{3}{*}{ Thorax volume } & normal weight & overweight & -5.89499 & $.000 * *$ \\
\hline & normal weight & obese & -17.4352 & $.000 * *$ \\
\hline & overweight & obese & -11.5402 & $.000 * *$ \\
\hline \multirow{3}{*}{ Upper arm volume } & normal weight & overweight & -2.24444 & $.000 * *$ \\
\hline & normal weight & obese & -5.97547 & $.000 * *$ \\
\hline & overweight & obese & -3.73103 & $.000 * *$ \\
\hline \multirow{3}{*}{ Thigh volume } & normal weight & overweight & -4.07450 & $.000 * *$ \\
\hline & normal weight & obese & -11.0419 & $.000 * *$ \\
\hline & overweight & obese & -6.96743 & $.000 * *$ \\
\hline \multirow{3}{*}{ Calf volume } & normal weight & overweight & -1.97794 & $.000 * *$ \\
\hline & normal weight & obese & -6.66415 & $.000 * *$ \\
\hline & overweight & obese & -4.68621 & $.000 * *$ \\
\hline \multirow{3}{*}{ Triceps skin fold } & normal weight & overweight & -3.53064 & $.000 * *$ \\
\hline & normal weight & obese & -9.07547 & $.000 * *$ \\
\hline & overweight & obese & -5.54483 & $.000 * *$ \\
\hline \multirow{3}{*}{ Sub-scapular skin fold } & normal weight & overweight & -4.26096 & $.001 * *$ \\
\hline & normal weight & obese & -8.48050 & $.000 * *$ \\
\hline & overweight & obese & -4.21954 & $.035^{*}$ \\
\hline \multirow{3}{*}{ Abdominal skin fold } & normal weight & overweight & -4.90618 & $.001 * *$ \\
\hline & normal weight & obese & -12.7828 & $.000 * *$ \\
\hline & overweight & obese & -7.87663 & $.001 * *$ \\
\hline \multirow{3}{*}{ Thigh skin fold } & normal weight & overweight & -5.09909 & $.000 * *$ \\
\hline & normal weight & obese & -9.06499 & $.000 * *$ \\
\hline & overweight & obese & -3.96590 & $.046^{*}$ \\
\hline \multirow{3}{*}{ Medial calf skin fold } & normal weight & overweight & -3.48133 & $.000 * *$ \\
\hline & normal weight & obese & -6.98784 & $.000 * *$ \\
\hline & overweight & obese & -3.50651 & $.015^{*}$ \\
\hline
\end{tabular}

Legend: Sig. - significance level; Mean Diff. - differences in mean values between the groups; statistical significance of differences $* * p<.01, * p<.05$ 
Table 3 shows Intergroup differences (LSD Post Hoc test) in morphological characteristics. The results indicate that groups of normal weight, overweight and obese subjects have significant differences in almost all morphological characteristics. Statistically significant difference wasn't detected only between normal and overweight subjects in measures of longitudinal dimensionality. Based of differences in mean values between the groups we can conclude that obese subjects had the highest results in parameters of morphological characteristics, followed by overweight, while the normal weight subjects had the lowest results.

\section{DISCUSSION}

Normal pediatric nutrition is an important factor in their proper, harmonious growth and development. On the other hand, we are witnessing that the modern way of life, both in developed and developing countries, has led to an altered lifestyle. A large number of studies indicate that lack of physical activity and irregular (overly) nutrition are the main causes of the development of a positive trend of obesity worldwide, at the level of all age groups (Burke, 2006; Lobstein et al., 2004; Roberts, Lucas, \& Hirsch, 2000; Lustig, 2006). Also, obesity carries with it the risk of developing a number of non-infectious diseases such as cardiovascular disease, type 2 diabetes, and many others. The mere fact that obese children have a greater prevalence of staying obese and in the adult age (Biro \& Wien, 2010; Bukara-Radujković \& Zdravković, 2009), enough talk about the importance of the problem itself

The results obtained in this study indicate that there are significant differences in morphological characteristics between normal weight, overweight and obese girls. The highest results were recorded in obese, followed by overweight, while normal weight girls had the lowest results. The highest difference was observed in body weight and voluminosity, as well as in subcutaneous fat tissue. Differences found in morphological characteristics in the eight-year-old girls with different levels of the nutrition are consistent, in an direct or indirect manner, with the previous research (Tokmakidis, Kasambalis, \& Christodoulos, 2006; Deforche et al., 2003; Grund et al., 2000; Wells et al., 2006; Đorđević \& Kostić, 2015). It is expected that, compared to normal weight, overweight and obese girls due to the increased body mass and greater development of fat tissue, will have significantly higher results and transversal dimensionalities of skeleton (especially in the pelvic and hip area).

Obesity in children and adolescents leads to various health problems. In addition to health disorders, in these children there is a stagnation in motor development, a decrease in the level of functional abilities, the appearance of muscular insufficiency, which is the cause of numerous bodily deformities (Bala, 2007; Graf et al., 2004a, 20046; De Sá Pinto, De Barros Holanda, Radu, Villares, \& Lima, 2006). In addition to somatic consequences of obesity, complex psychological and social aspects should not be neglected. An unfavorable picture 
of the appearance of one's own body, a lower level of self-confidence, and social isolation that deepens psychological problems, induce the introduction of larger amounts of food to alleviate the sense of discomfort, which closes the vicious circle (Hillman, Huang, \& Dorn, 2008; Tiggemann, 2005).

Regular and properly dosed physical activity is one of the important factors for the healthy physical and mental development of children (Dencker \& Andersen, 2008; Ortega, Ruiz, Castillo, \& Sjöström, 2008). When it comes to children, in the last decades there has been a significant decline in physical activity (Ogden, Flegal, Carrol, \& Johnson, 2002; Troiano, 2002). Instead of playing and sports, kids spend more and more time watching television or with computers. Troiano (2002) suggests that there is a direct correlation between an increase in obesity and an average daily time spent watching television.

\section{CONCLUSION}

Preventing obesity in children is of great importance, since created habits in this period of life are usually retained later throughout adulthood (Guo, Roche, Chumlee, Gardner, \& Siervogel, 1994; Zametkin, Zoon, Klein, \& Munson, 2004). Differences in morphological characteristics may provide some guidelines for the implementation of obesity prevention programs aimed at school population. The fact that spontaneous physical activity of children going to school significantly reduces compared to the activity of children from the period they start to learn how to walk until preschool period, requires involvement of health services, families, schools and other individuals in order to encourage healthy lifestyles and create positive habits related to physical activity. During the realization of the physical education program, teachers should apply specific procedures in dealing with obese children, so that these programs could have appropriate positive effects. Regular aerobic activity reduces body weight, improves the activity of cardiovascular and respiratory system and increases the level of individual motor abilities, which is why it is necessary for school, parents, health workers and teachers of physical education to react accordingly.

\section{Acknowledgement}

In this study we used results obtained in doctorate dissertation by Đorđević, M. (2015). Trend of changes in morpho-motoric status of girls varying degrees of nutritional status. Unpublished doctorate dissertation, Niš: Faculty of sport and physical education.

\section{REFERENCES}

Bala, G. (2007). Morfološke karakteristike predškolske dece. U: G. Bala (Ur.), Antropološke karakteristike i sposobnosti predškolske dece. Novi Sad: Fakultet sporta i fizičkog vaspitanja.33-66. 
Biro, F.M., \& Wien, M. (2010). Childhood obesity and adult morbidities. The American Journal of Clinical Nutrition, 91(5), 1499-1505. doi:10.3945/ajen.2010.28701B

Bukara-Radujković, G., \& Zdravković, D. (2009). Physical activity as an important determinant in developing childhood obesity. Medicinski pregled, 62(34), 107-113. doi:10.2298/MPNS0904107B

Burke, V. (2006). Obesity in childhood and cardiovascular risk. Clin. Exp. Pharmacol. Physiol., 33(9), 831-837. pmid:16922816. doi:10.1111/j.14401681.2006.04449.x

Cole, T.J., Bellizzi, M.C., Flegal, K.M., \& Dietz, W.H. (2000). Establishing a standard definition for child overweight and obesity worldwide: International survey. BMJ, 320(7244), 1240-1243. pmid:10797032. doi:10.1136/bmj.320.7244.1240

De Sá Pinto, A.L., De Barros Holanda, P.M., Radu, A.S., Villares, S.M., \& Lima, F.R. (2006). Musculoskeletal findings in obese children. Journal of Paediatrics and Child Health, 42(6), 341-344. doi:10.1111/j.14401754.2006.00869.x

Deforche, B., Lefevre, J., De, B.I., Hills, A.P., Duquet, W., \& Bouckaert, J. (2003). Physical fitness and physical activity in obese and nonobese Flemish youth. Obes. Res., 11(3), 434-441. pmid:12634442. doi:10.1038/oby.2003.59

Dencker, M., \& Andersen, L.B. (2008). Health-related aspects of objectively measured daily physical activity in children. Clin Physiol Funct Imaging, 28(3), 133-144. pmid:18241209. doi:10.1111/j.1475097X.2008.00788.X

Đorđević, M.M., \& Kostić, R.M. (2015). Morfološke karakteristike i stepen uhranjenosti kod sedmogodišnjih devojčica. Sinteze - časopis za pedagoške nauke, književnost i kulturu, 4(8), 77-87. doi:10.5937/sinteze0-9903

Goran, M.I. (2001). Metabolic precursors and effects of obesity in children: A decade of progress, 1990-1999. Am. J. Clin. Nutr., 73(2), 158-171. pmid: 11157310

Graf, C., Koch, B., Dordel, S., Schindler-Marlow, S., Icks, A., Schüller, A., . . Predel, H.G. (2004). Physical activity, leisure habits and obesity in firstgrade children. European Journal of Cardiovascular Prevention \& Rehabilitation, 11(4), 284-290. doi:10.1097/01.hjr.0000129740.30593.18

Graf, C., Koch, B., Kretschmann-Kandel, E., Falkowski, G., Christ, H., Coburger, S., . . . Dordel, S. (2004). Correlation between BMI, leisure habits and motor abilities in childhood (CHILT-project). International Journal Of Obesity, 28(1), 22-26. doi:10.1038/sj.ijo.0802428

Grund, A., Dilba, B., Forberger, K., Krause, H., Siewers, M., Rieckert, H., \& Müller, M.J. (2000). Relationships between physical activity, physical fitness, muscle strength and nutritional state in 5- to 11-year-old children. Eur. J. Appl. Physiol., 82(5-6), 425-438. pmid:10985597. doi:10.1007/s004210000197 
Guo, S.S., Roche, A.F., Chumlea, W.C., Gardner, J.D., \& Siervogel, R.M. (1994). The predictive value of childhood body mass index values for overweight at age 35 y. Am. J. Clin. Nutr., 59(4), 810-819. pmid:8147324

Hillman, J.B., Huang, B., \& Dorn, L.D. (2008). The Association of Anxiety and Depressive Symptoms with Obesity Among Adolescent Females: Looking Beyond Body Mass Index. Journal of Adolescent Health, 42(2), 42-43. doi:10.1016/j.jadohealth.2007.11.111

Lobstein, T., Baur, L., \& Uauy, R. (2004). Obesity in children and young people: A crisis in public health. Obesity Reviews, 5, 4-85. doi:10.1111/j.1467789X.2004.00133.X

Lustig, R.H. (2006). Childhood obesity: Behavioral aberration or biochemical drive? Reinterpreting the First Law of Thermodynamics. Nature Clinical Practice Endocrinology \& Metabolism, 2(8), 447-458. doi:10.1038/ncpendmet0220

Malacko, J. (1991). Osnove sportskog treninga : Kibernetički pristup. Novi Sad: FTN.

Ogden, C.L., Flegal, K.M., Carroll, M.D., \& Johnson, C.L. (2002). Prevalence and trends in overweight among US children and adolescents, 19992000. JAMA, 288(14), 1728-1732. pmid:12365956.

doi:10.1001/jama.288.14.1728

Ortega, F.B., Ruiz, J.R., Castillo, M.J., \& Sjöström, M. (2007). Physical fitness in childhood and adolescence: A powerful marker of health. International Journal of Obesity, 32(1), 1-11. doi:10.1038/sj.ijo.0803774

Peco-Antić, A. (2009). Hypertension in Obese Children and Adolescents. Srpski arhiv za celokupno lekarstvo, 137(1-2), 91-97. doi:10.2298/SARH0902091P

Roberts, S.B., Lucas, A., \& Hirsch, J. (2000). Low energy expenditure as a contributor to infant obesity. Am. J. Clin. Nutr., 71(1), 154-155. pmid:10617962

Tiggemann, M. (2005). Body dissatisfaction and adolescent self-esteem: Prospective findings. Body Image, 2(2), 129-135. doi:10.1016/j.bodyim.2005.03.006

Tokmakidis, S.P., Kasambalis, A., \& Christodoulos, A.D. (2006). Fitness levels of Greek primary schoolchildren in relationship to overweight and obesity. Eur. J. Pediatr., 165(12), 867-874. pmid:16775723. doi:10.1007/s00431006-0176-2

Troiano, R.P. (2002). Physical inactivity among young people. N. Engl. J. Med., 347(10), 706-707. pmid:12213940. doi:10.1056/NEJMp020085

Weiner, J.S., \& Lourie, J.A. (1969). Human Biology: A Guide to Field Methods. Oxford: International Biological Programme by Blackwell Scientific.

Wells, J.C.K., Fewtrell, M.S., Williams, J.E., Haroun, D., Lawson, M.S., $\&$ Cole, T.J. (2006). Body composition in normal weight, overweight and obese 
children: Matched case-control analyses of total and regional tissue masses, and body composition trends in relation to relative weight. International Journal of Obesity, 30(10), 1506-1513. doi:10.1038/sj.ijo.0803402

Zametkin, A.J., Zoon, C.K., Klein, H.W., \& Munson, S. (2004).

Psychiatric Aspects of Child and Adolescent Obesity: A Review of the Past 10 Years. Journal of the American Academy of Child \& Adolescent Psychiatry, 43(2), 134-150. doi:10.1097/00004583-200402000-00008

\title{
МОРФОЛОШКИ СТАТУС ОСМОГОДИШЫИХ ДЕВОЈЧИЦА РАЗЛИЧИТОГ СТЕПЕНА УХРАЮЕНОСТИ
}

\author{
Марија, М. Ђорђевић ${ }^{1}$ и Бојан J. Митровић ${ }^{2}$
}

Сажетак. Степен ухрањености деце један је од важнијих показатеља њиховог здравља, психофизичких могућности и потенцијала за нормалан и здрав раст и развој. Циљ студије био је да се утврде разлике у морфолошким карактеристикама код осмогодишњих девојчица различитог степена ухрањености. Истраживање је спроведено на узорку од 91 девојчице другог разреда основних школа града Ниша, просечне године старости 8.06 ( \pm 0.02). На основу BMI, формирана су три субузорка (нормално ухрањене, прекомерно ухрањене и гојазне испитанице). Морфолошки статус утврђен је мерењем параметара лонгитудиналне, трансверзалне и циркуларне димензионалности, масе тела и поткожног масног ткива. Разлике у морфолошким карактеристикама утврђене су MANOVA/ANOVA-oм и LSD Post Нос тестом. Резултати студије указују да у односу на степен ухрањености постоји значајна разлика у морфолошком статусу код осмогодишњих девојчица. Највеће вредности забележене су код гојазних, затим прекомерно ухрањених, док су најмање вредности имале нормално ухрањене испитанице.

Кључне речи: разлике, основна школа, девојчице, морфолошке карактеристике, степен ухрањености.

\footnotetext{
1 mdjordjevic@vaspks.edu.rs, Висока школа струковних студија за васпитаче, Крушевац

2 bokimitrovic976@gmail.com, Одељење за стручно образовање и обуку, Министарство унутрашњих послова, Београд
} 


\title{
МОРФОЛОШКИ СТАТУС ОСМОГОДИШЬИХ ДЕВОЈЧИЦА РАЗЛИЧИТОГ СТЕПЕНА УХРАЮЕНОСТИ
}

\author{
Марија, М. Борђевић ${ }^{1}$ и Бојан J. Митровић ${ }^{2}$
}

Сажетак. Степен ухрањености деце један је од важнијих показатеља њиховог здравља, психофизичких могућности и потенцијала за нормалан и здрав раст и развој. Циљ студије био је да се утврде разлике у морфолошким карактеристикама код осмогодишњих девојчица различитог степена ухрањености. Истраживање је спроведено на узорку од 91 девојчице другог разреда основних школа града Ниша, просечне године старости 8.06 ( \pm 0.02). На основу ВMI, формирана су три субузорка (нормално ухрањене, прекомерно ухрањене и гојазне испитанице). Морфолошки статус утврђен је мерењем параметара лонгитудиналне, трансверзалне и циркуларне димензионалности, масе тела и поткожног масног ткива. Разлике у морфолошким карактеристикама утврђене су MANOVA/ANOVA-ом и LSD Post Нос тестом. Резултати студије указују да у односу на степен ухрањености постоји значајна разлика у морфолошком статусу код осмогодишњих девојчица. Највеће вредности забележене су код гојазних, затим прекомерно ухрањених, док су најмање вредности имале нормално ухрањене испитанице.

Кључне речи: разлике, основна школа, девојчице, морфолошке карактеристике, степен ухрањености.

\section{УВОД}

Под морфолошким карактеристикама антрополошког статуса човека најчеће се подразумева систем основних антропометријских латентних димензија (Malacko, 1991). Идентификација латентних димензија у овом

\footnotetext{
1 mdjordjevic@vaspks.edu.rs, Висока школа струковних студија за васпитаче, Крушевац

2 bokimitrovic976@gmail.com, Одељење за стручно образовање и обуку, Министарство унутрашњих послова, Београд
} 
простору, добијена је применом факторских математичко-статистичких поступака, помоћу којих су изоловани антропометријски фактори, а који су из серије манифестних варијабли (антропометријске мере које се могу директно мерити) дефинисани као латентне морфолошке димензије. Факторским приступом, у морфолошком простору, идентификована су четири основна фактора, који су дали почетне информације о структури морфолошких димензија, као и о неким хијерархијским односима у тој структури. Морфолошку структуру човека чини лонгитудинална димензионалнпост скелета, трансверзална димензионалност скелета, маса и волумен тела и поткожно масно ткиво. У односу на узраст и пол ови фактори се понекад повезују тако да формирају два генерална фактора: димензионалност скелета (лонгитудинална и трансверзална) и волуминозност тела (волумен тела и поткожно масно ткиво). Информације о структури морфолошког статуса веома су битне са аспекта њихове трансформације (раст и развој). Морфолошке карактеристике претежно су под утицајем генетских фактора и фактора околине. Ендогени утицај није исти за све морфолошке димензије. Коефицијент урођености за димензионалност скелета износи .98 , волуминозност тела .90 , а за масно ткиво .50.

Млађи школски узраст представља веома сензитивно развојно доба. Велика пажња научне јавности усмерена је на телесни статус деце, указујући на забрињавајућу преваленцију прекомерно ухрањене и гојазне деце. Код деце и адолесцената гојазност се дефинише као повећање телесне масе изнад референтних вредности за одређени узраст, пол и телесну висину, чији је резултат повећање количине масти у организму (Реco-Antić, 2009). Појава гојазности током детињства и адолесценције повећава могућност за гојазност особе и у одраслом добу. Утврђено је да се гојазност код девојчица у $30 \%$, а код дечака у $10 \%$ случајева јавља и касније у зрелом добу (Goran, 2001).

Ухрањеност деце један је од важних показатеља њиховог здравља, психофизичких могућности и потенцијала за нормалан и здрав раст и развој (Lobstein, Baur, \& Uauy, 2004). Свако веће одступање од оптималне телесне масе код деце повећава ризик за појаву и развој многих незарасних болести током живота.

Циљ истраживања био је да се утврде разлике у морфолошким карактеристикама код осмогодишњих девојчица различитог степена ухрањености.

\section{МЕТОД \\ Узорак испитаника}

Истраживање је спроведено на узорку од 91 девојчице, ученице другог разреда основних школа града Ниша. Просечна старост испитаница 
била је 8.06 ( \pm 0.02$)$. Све испитанице на дан тестирања биле су здраве и имале су писану сагласност родитеља и директора школе за учествовању у истраживању. Мерења су спроведена у школама за време наставе физичког васпитања.

Након мерења телесне висине и масе тела и израчунавања вредности BMI (Cole, Bellizzi, Flegal, \& Dietz, 2000), формирана су три субузорка. Први субузорак чинило је 53 нормално ухрањених девојчица, са просечним вредностима BMI 16.00 ( \pm 1.69$)$. Други субузорак чинило је 29 прекомерно ухрањених девојчица, са просечним вредностима BMI 19.40 ( \pm 0.66). Трећи субузорак чинило је 9 гојазних девојчица, са просечним вредностима ВМI $24.37( \pm 1.62)$.

\section{Мерни инструменти}

Морфолошки статус утврђен је мерењем параметара: лонгитудиналне димензионалности (телесна висина, дужина руке, дужина ноге), трансверзалне димензионалности (ширина рамена, ширина кукова, ширина карлице), циркуларне димензионалности и масе тела (средњи обим груди, обим надлакта, обим бутине, обим потколенице) и поткожног масног ткива (кожни набор надлакта, кожни набор леђа, кожни набор трбуха, кожни набор бутине, кожни набор потколенице).

За мерење морфолошких карактеристика примењени су стандардизовани мерни инструменти по методи коју препоручује Интернационални биолошки програм (International Biological Programme) (Weiner \& Lourie, 1969).

\section{Методе обраде података}

За све мерене параметре израчуната је средња вредност и стандардна девијација. Разлике између група у морфолошким карактеристикама утврђене су применом мултиваријентне и униваријантне анализе варијансе (MANOVA/ANOVA). Разлике поређењем група утврђене су LSD Post Hoc тестом. За обраду и анализу сирових података коришћен је статистички пакет Statistical Package for the Social Science (SPSS), верзија 18.0.

\section{РЕЗУЛТАТИ}

На Табели 1 приказани су основни параметри дескриптивне статистике морфолошких варијабли нормално ухрањених, прекомерно ухрањених и гојазних испитаница. 
Табела 1. Основни параметри дескриптивне статистике

\begin{tabular}{|l|ll|ll|ll|}
\hline \multicolumn{1}{|c}{$\begin{array}{l}\text { Нормално } \\
\text { ухрањене }\end{array}$} & \multicolumn{3}{l}{$\begin{array}{l}\text { Прекомерно } \\
\text { ухрањене }\end{array}$} \\
\hline & Mean & SD & Mean & SD & Mean & SD \\
\hline Телесна висина & 133.12 & 6.80 & 133.93 & 5.57 & 141.19 & 4.87 \\
Дужина ноге & 74.29 & 4.49 & 73.85 & 4.54 & 79.82 & 3.67 \\
Дужина руке & 55.83 & 3.32 & 56.09 & 3.36 & 59.94 & 2.61 \\
Ширина рамена & 28.77 & 2.02 & 29.67 & 1.53 & 32.20 & 1.31 \\
Ширина карлице & 20.60 & 1.40 & 21.86 & 1.26 & 25.54 & 3.08 \\
Ширина кукова & 22.25 & 1.39 & 23.77 & 1.49 & 26.03 & 1.41 \\
Телесна маса & 28.50 & 4.60 & 34.87 & 3.38 & 48.67 & 5.10 \\
Об. грудног коша & 61.10 & 7.05 & 66.99 & 3.75 & 78.53 & 5.06 \\
Об. надлакта & 18.62 & 1.97 & 20.87 & 1.41 & 24.60 & 1.56 \\
Об. бутине & 37.74 & 4.18 & 41.81 & 3.66 & 48.78 & 2.63 \\
Об. потколенице & 26.94 & 2.23 & 28.91 & 1.79 & 33.60 & 0.97 \\
КН надлакта & 11.32 & 3.97 & 14.86 & 3.42 & 20.40 & 3.48 \\
КН леђа & 8.25 & 5.69 & 12.51 & 3.87 & 16.73 & 5.59 \\
КН трбуха & 10.73 & 6.90 & 15.63 & 4.64 & 23.51 & 6.05 \\
КН бутине & 14.09 & 4.76 & 19.19 & 5.04 & 23.16 & 7.35 \\
КН потколенице & 12.66 & 3.88 & 16.14 & 3.18 & 19.64 & 4.22 \\
\hline
\end{tabular}

Легенда: Меап - средња вредност; SD - стандардна девијација; KH кожни набор;Об.- Обим

На основу добијених резултата може се констатовати да, у односу на нормално и прекомерно ухрањене, гојазне испитанице имају највеће вредности у свим морфолошким варијаблима.

На Табели 2 приказане су мултиваријантна и униваријантна анализа варијансе у морфолошким варијаблама између нормално ухрањених, прекомерно ухрањених и гојазних испитаница. Анализом резултата (Табела 2) може се констатовати да у морфолошком простору, на мултиваријантном нивоу, постоји статистички значајна међугрупна разлика (.00). Резултати униваријантне анализе варијансе (Табела 2) указују да су међугрупне разлике статистички значајне у свим варијаблама морфолошких карактеристика на нивоу значајности од .01. 
Табела 2. Мултиваријантна и униваријантна анализа варијансе у морфолошким карактеристикама испитаница различитог степена ухрањености

\begin{tabular}{lll}
\hline & $\mathrm{F}$ & Sig. \\
\hline Телесна висина & 6.41 & $.003 * *$ \\
Дужина ноге & 6.75 & $.002 * *$ \\
Дужина руке & 6.16 & $.003 * *$ \\
Ширина рамена & 14.11 & $.000 * *$ \\
Ширина карлице & 38.41 & $.000 * *$ \\
Ширина кукова & 31.60 & $.000 * *$ \\
Телесна маса & 90.95 & $.000 * *$ \\
Обим грудног коша & 35.43 & $.000 * *$ \\
Обим надлакта & 49.76 & $.000 * *$ \\
Обим бутине & 34.85 & $.000 * *$ \\
Обим потколенице & 44.76 & $.000 * *$ \\
Кожни набор надлакта & 25.84 & $.000 * *$ \\
Кожни набор леђа & 13.72 & $.000 * *$ \\
Кожни набор трбуха & 18.80 & $.000 * *$ \\
Кожни набор бутине & 17.35 & $.000 * *$ \\
Кожни набор потколенице & 18.05 & $.000 * *$ \\
\hline
\end{tabular}

Wilk's $=0.122 \quad \mathrm{~F}=8.48 \quad \mathrm{p}=.000^{* *}$

Легенда:Wilk's - Tecm Wilksove ламбде; $F$ - Раова $F$ апроксимација; $p$

(Sig.) - ниво значајности; статистичка значајност разлика ** $p<.01$

Међугрупне разлике (LSD Post Нос тест) у морфолошким карактеристикама приказане су на Табели 3.

Добијени резултати указују да се групе нормално ухрањених, прекомерно ухрањених и гојазних испитаница статистички значајно разликују у скоро свим морфолошким карактеристикама. Статистички значајна разлика није забележена једино између нормално и прекомерно ухрањених испитаница у мерама лонгитудиналне димензионалности. На основу разлика средњих вредности између група може се констатовати да су гојазне испитанице имале највеће вредности у свим параметрима морфолошких карактеристика, затим следе прекомерно ухрањене, док су нормално ухрањене испитанице имале најмање вредности. 
Табела 3. Међугрупне разлике у морфолошким карактеристикама

\begin{tabular}{|c|c|c|c|c|}
\hline & ГРУПЕ & & Mean D & ff. Sig. \\
\hline $\begin{array}{l}\text { Телесна } \\
\text { висина }\end{array}$ & $\begin{array}{l}\text { нормално } \\
\text { нормално } \\
\text { прекомерно }\end{array}$ & $\begin{array}{l}\text { прекомерно } \\
\text { гојазне } \\
\text { гојазне }\end{array}$ & $\begin{array}{r}-.81594 \\
-8.07379 \\
-7.25785 \\
\end{array}$ & $\begin{array}{r}.575 \\
.001 * * \\
.003 * *\end{array}$ \\
\hline $\begin{array}{l}\text { Дужина } \\
\text { ноге }\end{array}$ & $\begin{array}{l}\text { нормално } \\
\text { нормално } \\
\text { прекомерно }\end{array}$ & $\begin{array}{l}\text { прекомерно } \\
\text { гојазне } \\
\text { гојазне }\end{array}$ & $\begin{array}{l}.44418 \\
-5.52977 \\
-5.97395 \\
\end{array}$ & $\begin{array}{r}.666 \\
.001^{* *} \\
.001^{* *}\end{array}$ \\
\hline $\begin{array}{l}\text { Дужина } \\
\text { руке }\end{array}$ & $\begin{array}{l}\text { нормално } \\
\text { нормално } \\
\text { прекомерно }\end{array}$ & $\begin{array}{l}\text { прекомерно } \\
\text { гојазне } \\
\text { гојазне }\end{array}$ & $\begin{array}{l}.25224 \\
-4.11048 \\
-3.85824 \\
\end{array}$ & $\begin{array}{l}.740 \\
.001 * * \\
.003 * *\end{array}$ \\
\hline Ширина рамена & $\begin{array}{l}\text { нормално } \\
\text { нормално } \\
\text { прекомерно }\end{array}$ & $\begin{array}{l}\text { прекомерно } \\
\text { гојазне } \\
\text { гојазне } \\
\end{array}$ & $\begin{array}{l}.89915 \\
-3.43019 \\
-2.53103 \\
\end{array}$ & $\begin{array}{l}.035^{*} \\
.000^{*} * \\
.000^{* *}\end{array}$ \\
\hline Ширина карлице & $\begin{array}{l}\text { нормално } \\
\text { нормално } \\
\text { прекомерно }\end{array}$ & $\begin{array}{l}\text { прекомерно } \\
\text { гојазне } \\
\text { гојазне } \\
\end{array}$ & $\begin{array}{l}-1.25830 \\
-4.94067 \\
-3.68238 \\
\end{array}$ & $\begin{array}{l}.001 * * \\
.000^{* * *} \\
.000^{* *}\end{array}$ \\
\hline $\begin{array}{l}\text { Ширина } \\
\text { кукова }\end{array}$ & $\begin{array}{l}\text { нормално } \\
\text { нормално } \\
\text { прекомерно }\end{array}$ & $\begin{array}{l}\text { прекомерно } \\
\text { гојазне } \\
\text { гојазне } \\
\end{array}$ & $\begin{array}{r}-1.51080 \\
-3.77862 \\
-2.26782 \\
\end{array}$ & $\begin{array}{l}.000^{* * *} \\
.000^{* *} \\
.000^{* *}\end{array}$ \\
\hline $\begin{array}{l}\text { Телесна } \\
\text { маса }\end{array}$ & $\begin{array}{l}\text { нормално } \\
\text { нормално } \\
\text { прекомерно }\end{array}$ & $\begin{array}{l}\text { прекомерно } \\
\text { гојазне } \\
\text { гојазне } \\
\end{array}$ & $\begin{array}{l}-6.37241 \\
-20.1666 \\
-13.7942 \\
\end{array}$ & $\begin{array}{l}.000^{* * *} \\
.000^{* * *} \\
.000^{* *} *\end{array}$ \\
\hline $\begin{array}{l}\text { Обим } \\
\text { грудног коша }\end{array}$ & $\begin{array}{l}\text { нормално } \\
\text { нормално } \\
\text { прекомерно }\end{array}$ & $\begin{array}{l}\text { прекомерно } \\
\text { гојазне } \\
\text { гојазне }\end{array}$ & $\begin{array}{l}-5.89499 \\
-17.4352 \\
-11.5402 \\
\end{array}$ & $\begin{array}{l}.000^{* *} \\
.000^{* *} \\
.000^{* *}\end{array}$ \\
\hline $\begin{array}{l}\text { Обим } \\
\text { надлакта }\end{array}$ & $\begin{array}{l}\text { нормално } \\
\text { нормално } \\
\text { прекомерно }\end{array}$ & $\begin{array}{l}\text { прекомерно } \\
\text { гојазне } \\
\text { гојазне }\end{array}$ & $\begin{array}{l}-2.24444 \\
-5.97547 \\
-3.73103 \\
\end{array}$ & $\begin{array}{l}.000^{* *} * \\
.000^{*} * \\
.000^{* * *}\end{array}$ \\
\hline $\begin{array}{l}\text { Обим } \\
\text { бутине }\end{array}$ & $\begin{array}{l}\text { нормално } \\
\text { нормално } \\
\text { прекомерно }\end{array}$ & $\begin{array}{l}\text { прекомерно } \\
\text { гојазне } \\
\text { гојазне } \\
\end{array}$ & $\begin{array}{l}-4.07450 \\
-11.0419 \\
-6.96743 \\
\end{array}$ & $\begin{array}{l}.000^{* *} \\
.000^{* *} * \\
.000^{* *}\end{array}$ \\
\hline $\begin{array}{l}\text { Обим } \\
\text { потколенице }\end{array}$ & $\begin{array}{l}\text { нормално } \\
\text { нормално } \\
\text { прекомерно }\end{array}$ & $\begin{array}{l}\text { прекомерно } \\
\text { гојазне } \\
\text { гојазне }\end{array}$ & $\begin{array}{l}-1.97794 \\
-6.66415 \\
-4.68621 \\
\end{array}$ & $\begin{array}{l}.000^{* *} \\
.000^{* *} \\
.000^{* *} *\end{array}$ \\
\hline КН надлакта & $\begin{array}{l}\text { нормално } \\
\text { нормално } \\
\text { прекомерно }\end{array}$ & $\begin{array}{l}\text { прекомерно } \\
\text { гојазне } \\
\text { гојазне } \\
\end{array}$ & $\begin{array}{l}-3.53064 \\
-9.07547 \\
-5.54483 \\
\end{array}$ & $\begin{array}{l}.000^{* *} \\
.000^{* *} * \\
.000^{* *}\end{array}$ \\
\hline КН леђа & $\begin{array}{l}\text { нормално } \\
\text { нормално } \\
\text { прекомерно }\end{array}$ & $\begin{array}{l}\text { прекомерно } \\
\text { гојазне } \\
\text { гојазне }\end{array}$ & $\begin{array}{l}-4.26096 \\
-8.48050 \\
-4.21954 \\
\end{array}$ & $\begin{array}{l}.001 * * \\
.000^{* *} * \\
.035^{*}\end{array}$ \\
\hline КН трбуха & $\begin{array}{l}\text { нормално } \\
\text { нормално } \\
\text { прекомерно }\end{array}$ & $\begin{array}{l}\text { прекомерно } \\
\text { гојазне } \\
\text { гојазне }\end{array}$ & $\begin{array}{l}-4.90618 \\
-12.7828 \\
-7.87663 \\
\end{array}$ & $\begin{array}{l}.001 * * \\
.000 * * \\
.001 * *\end{array}$ \\
\hline КН бутине & $\begin{array}{l}\text { нормално } \\
\text { нормално } \\
\text { прекомерно }\end{array}$ & $\begin{array}{l}\text { прекомерно } \\
\text { гојазне } \\
\text { гојазне }\end{array}$ & $\begin{array}{l}-5.09909 \\
-9.06499 \\
-3.96590 \\
\end{array}$ & $\begin{array}{l}.000^{* *} \\
.000^{* *} \\
.046 *\end{array}$ \\
\hline КН потколенице & $\begin{array}{l}\text { нормално } \\
\text { нормално } \\
\text { прекомерно }\end{array}$ & $\begin{array}{l}\text { прекомерно } \\
\text { гојазне } \\
\text { гојазне }\end{array}$ & $\begin{array}{l}-3.48133 \\
-6.98784 \\
-3.50651\end{array}$ & $\begin{array}{l}.000^{* * *} \\
.000^{* * *} \\
.015^{*}\end{array}$ \\
\hline
\end{tabular}

Легенда: Sig. - ниво значајности; Mean Diff. - разлика у средњим вредностима између група; статистичка значајност разлика ** $p<.01,{ }^{*} p<.05$. 
Нормална ухрањеност деце представља битан фактор њиховог правилног, хармоничког раста и развоја. Са друге стране, сведоци смо да је савремени начин живота, како у развијеним тако и у земљама у развоју, довео до измењеног стила живљења. Велики број студија указује да су хипокинезија и неправилна (преобилна) исхрана основни узрочници развоја позитивног тренда гојазности широм света, и то на нивоу свих узрасних популација (Burke, 2006; Lobstein и остали, 2004; Lustig, 2006; Roberts, Lucas, \& Hirsch, 2000). Такође, гојазност са собом носи ризик за развој бројних неинфективних обољења као што су кардиоваскуларне болести, дијабетес тип 2 и многе друге. Сама чињеница да гојазна деца имају већу преваленцију да остану гојазна и у одраслом добу (Biro \& Wien, 2010; Bukara-Radujković \& Zdravković, 2009) довољно говори о важности самог проблема.

Резултати нашег истраживања потврђују значајне разлике у морфолошком статусу између девојчица различитог степена ухрањености. Највеће вредности имале су гојазне, затим следе прекомерно ухрањене док су нормално ухрањене имале најмање вредности. Највећа разлика била је забележена у маси и волуминозности тела, као и у поткожном масном ткиву. Утврђене разлике у морфолошким карактеристикама код осмогодишњих девојчица различитог степена ухрањености у сагласности су са досадашњим истраживањима (Deforche и остали, 2003; Đorđević \& Kostić, 2015; Grund и остали, 2000; Tokmakidis, Kasambalis, \& Christodoulos, 2006; Wells и остали, 2006). Очекивано је да ће, у односу на нормално ухрањене, прекомерно ухрањене и гојазне испитанице услед увећане масе тела и веће развијености адипозног ткива имати значајно веће вредности и трансверзалне димензионалности скелета (посебно у пределу карлице и кукова).

Гојазност код деце и адолесцената доводи до различитих здравствених проблема. Поред здравствених сметњи, код ове деце долази до застоја у моторичком развоју, опадања нивоа функционалних способности, јављања мишићне инсуфијенције која је узрок бројних телесних деформитет (Bala, 2007; De Sá Pinto, De Barros Holanda, Radu, Villares, \& Lima, 2006; C. Graf и остали, 2004; Christine Graf и остали, 2004). Поред соматских последица гојазности, не треба занемарити комплексне психолошке и социјалне аспекте. Неповољна слика о изгледу сопственог тела, нижи ниво самопоуздања, као и социјална изолација која продубљује психолошке проблеме, индукују уношење већих количина хране како би се ублажио осећај непријатности, чиме се затвара зачаран круг (Hillman, Huang, \& Dorn, 2008; Tiggemann, 2005).

Редовна и правилно дозирана физичка активност један је од битних фактора за здрав физички и ментални развој деце (Dencker \& Andersen, 2008; Ortega, Ruiz, Castillo, \& Sjöström, 2007). Када су деца у питању, 
последњих деценија дошло је до знатног опадања нивоа физичке активности (Ogden, Flegal, Carroll, \& Johnson, 2002; Troiano, 2002). Уместо у игри и спорту деца све више времена проводе гледајући телевизију или уз компјутер. Troiano (2002) указује да постоји директна повезаност између повећања гојазности и просечног дневног времена проведеног гледањем телевизије.

\section{ЗАКљУЧАК}

Превентива и едукација деце од посебне је важности с обзиром на то да се створене навике у овом периоду живота најчешће задржавају и касније у одраслом добу (Guo, Roche, Chumlea, Gardner, \& Siervogel, 1994; Zametkin, Zoon, Klein, \& Munson, 2004). Утврђене разлике у морфолошким карактеристикама могу дати одређене смернице за спровођење програма превенције гојазности за ову школску популацију. Чињеница да се спонтана физичка активност деце при поласку у школу значајно смањује у односу на ову активност деце од проходавања до предшколског узраста, додатно обавезује укључивање здравствене службе, породице, школе и других појединаца у циљу подстицања здравог стила живота и стварања позитивних навика везаних за физичку активност. У току реализације програма физичког васпитања наставници би требало да примењују специфичан поступак у раду са гојазном децом како би ти програми имали одговарајуће позитивне ефекте. Редовна активност аеробног карактера редукује телесну тежину, унапређује кардиоваскуларну и респираторну функцију и повећава ниво појединих моторичких способности због чега је неопходно правовремено и синхронизовано реаговање школе, родитеља, медицинских радника и наставника физичког васпитања и спорта.

Напомена

У овом раду коришћени су резултати добијени у докторској дисертацији Ђорђевић, М. (2015). Тренд промена морфо-моторичког статуса девојчица различитог степена ухрањености. Необјављена докторска дисертација, Ниш: Факултет спорта и физичког васпитања.

\section{ЛИТЕРАТУРА}

Bala, G. (2007). Morfološke karakteristike predškolske dece. U: G. Bala (Ur.), Antropološke karakteristike i sposobnosti predškolske dece. Novi Sad: Fakultet sporta i fizičkog vaspitanja.33-66.

Biro, F.M., \& Wien, M. (2010). Childhood obesity and adult morbidities. The American Journal of Clinical Nutrition, 91(5), 1499-1505. doi:10.3945/ajen.2010.28701B 
Bukara-Radujković, G., \& Zdravković, D. (2009). Physical activity as an important determinant in developing childhood obesity. Medicinski pregled, 62(34), 107-113. doi:10.2298/MPNS0904107B

Burke, V. (2006). Obesity in childhood and cardiovascular risk. Clin. Exp. Pharmacol. Physiol., 33(9), 831-837. pmid:16922816. doi:10.1111/j.14401681.2006.04449.x

Cole, T.J., Bellizzi, M.C., Flegal, K.M., \& Dietz, W.H. (2000). Establishing a standard definition for child overweight and obesity worldwide: International survey. BMJ, 320(7244), 1240-1243. pmid:10797032. doi:10.1136/bmj.320.7244.1240

De Sá Pinto, A.L., De Barros Holanda, P.M., Radu, A.S., Villares, S.M., \& Lima, F.R. (2006). Musculoskeletal findings in obese children. Journal of Paediatrics and Child Health, 42(6), 341-344. doi:10.1111/j.14401754.2006.00869.x

Deforche, B., Lefevre, J., De, B.I., Hills, A.P., Duquet, W., \& Bouckaert, J. (2003). Physical fitness and physical activity in obese and nonobese Flemish youth. Obes. Res., 11(3), 434-441. pmid:12634442. doi:10.1038/oby.2003.59

Dencker, M., \& Andersen, L.B. (2008). Health-related aspects of objectively measured daily physical activity in children. Clin Physiol Funct Imaging, 28(3), 133-144. pmid:18241209. doi:10.1111/j.1475097X.2008.00788.x

Đorđević, M.M., \& Kostić, R.M. (2015). Morfološke karakteristike i stepen uhranjenosti kod sedmogodišnjih devojčica. Sinteze - časopis za pedagoške nauke, književnost i kulturu, 4(8), 77-87. doi:10.5937/sinteze0-9903

Goran, M.I. (2001). Metabolic precursors and effects of obesity in children: A decade of progress, 1990-1999. Am. J. Clin. Nutr., 73(2), 158-171. pmid: 11157310

Graf, C., Koch, B., Dordel, S., Schindler-Marlow, S., Icks, A., Schüller, A., . . . Predel, H.G. (2004). Physical activity, leisure habits and obesity in firstgrade children. European Journal of Cardiovascular Prevention \& Rehabilitation, 11(4), 284-290. doi:10.1097/01.hjr.0000129740.30593.18

Graf, C., Koch, B., Kretschmann-Kandel, E., Falkowski, G., Christ, H., Coburger, S., . . . Dordel, S. (2004). Correlation between BMI, leisure habits and motor abilities in childhood (CHILT-project). International Journal Of Obesity, 28(1), 22-26. doi:10.1038/sj.ijo.0802428

Grund, A., Dilba, B., Forberger, K., Krause, H., Siewers, M., Rieckert, H., \& Müller, M.J. (2000). Relationships between physical activity, physical fitness, muscle strength and nutritional state in 5- to 11-year-old children. Eur. J. Appl. Physiol., 82(5-6), 425-438. pmid:10985597. doi:10.1007/s004210000197 
Guo, S.S., Roche, A.F., Chumlea, W.C., Gardner, J.D., \& Siervogel, R.M. (1994). The predictive value of childhood body mass index values for overweight at age 35 y. Am. J. Clin. Nutr., 59(4), 810-819. pmid:8147324

Hillman, J.B., Huang, B., \& Dorn, L.D. (2008). The Association of Anxiety and Depressive Symptoms with Obesity Among Adolescent Females: Looking Beyond Body Mass Index. Journal of Adolescent Health, 42(2), 42-43. doi:10.1016/j.jadohealth.2007.11.111

Lobstein, T., Baur, L., \& Uauy, R. (2004). Obesity in children and young people: A crisis in public health. Obesity Reviews, 5, 4-85. doi:10.1111/j.1467789X.2004.00133.X

Lustig, R.H. (2006). Childhood obesity: Behavioral aberration or biochemical drive? Reinterpreting the First Law of Thermodynamics. Nature Clinical Practice Endocrinology \& Metabolism, 2(8), 447-458. doi:10.1038/ncpendmet0220

Malacko, J. (1991). Osnove sportskog treninga : Kibernetički pristup. Novi Sad: FTN.

Ogden, C.L., Flegal, K.M., Carroll, M.D., \& Johnson, C.L. (2002). Prevalence and trends in overweight among US children and adolescents, 19992000. JAMA, 288(14), 1728-1732. pmid:12365956.

doi:10.1001/jama.288.14.1728

Ortega, F.B., Ruiz, J.R., Castillo, M.J., \& Sjöström, M. (2007). Physical fitness in childhood and adolescence: A powerful marker of health. International Journal of Obesity, 32(1), 1-11. doi:10.1038/sj.ijo.0803774

Peco-Antić, A. (2009). Hypertension in Obese Children and Adolescents. Srpski arhiv za celokupno lekarstvo, 137(1-2), 91-97. doi:10.2298/SARH0902091P

Roberts, S.B., Lucas, A., \& Hirsch, J. (2000). Low energy expenditure as a contributor to infant obesity. Am. J. Clin. Nutr., 71(1), 154-155. pmid:10617962

Tiggemann, M. (2005). Body dissatisfaction and adolescent self-esteem: Prospective findings. Body Image, 2(2), 129-135.

doi:10.1016/j.bodyim.2005.03.006

Tokmakidis, S.P., Kasambalis, A., \& Christodoulos, A.D. (2006). Fitness levels of Greek primary schoolchildren in relationship to overweight and obesity. Eur. J. Pediatr., 165(12), 867-874. pmid:16775723. doi:10.1007/s00431006-0176-2

Troiano, R.P. (2002). Physical inactivity among young people. N. Engl. J. Med., 347(10), 706-707. pmid:12213940. doi:10.1056/NEJMp020085

Weiner, J.S., \& Lourie, J.A. (1969). Human Biology: A Guide to Field Methods. Oxford: International Biological Programme by Blackwell Scientific.

Wells, J.C.K., Fewtrell, M.S., Williams, J.E., Haroun, D., Lawson, M.S., \& Cole, T.J. (2006). Body composition in normal weight, overweight and obese 
children: Matched case-control analyses of total and regional tissue masses, and body composition trends in relation to relative weight. International Journal of Obesity, 30(10), 1506-1513. doi:10.1038/sj.ijo.0803402

Zametkin, A.J., Zoon, C.K., Klein, H.W., \& Munson, S. (2004).

Psychiatric Aspects of Child and Adolescent Obesity: A Review of the Past 10 Years. Journal of the American Academy of Child \& Adolescent Psychiatry, 43(2), 134-150. doi:10.1097/00004583-200402000-00008

\title{
MORPHOLOGICAL STATUS OF EIGHT-YEAR-OLD GIRLS OF VARYING DEGREES OF NUTRITIONAL STATUS
}

\author{
Marija, M. Đorđević ${ }^{l}$ and Bojan, J. Mitrović ${ }^{2}$
}

Abstract: Nutritional status of children is one of the most important indicators of health, mental and physical capabilities and potential for normal and healthy growth and development. The aim of this study was to determine differences in morphological characteristics in eight-year-old girls with varying degrees of nutritional status. The research was conducted on a sample of 91 second grade students of elementary schools in Nis, aged $8.06( \pm 0.02)$. Based on the BMI, three sub-samples were formed (normal weight, overweight and obese subjects). Morphological status was determined by measuring the parameters of longitudinal, transversal and circular dimensionality, body weight and subcutaneous fatty tissue. Differences in morphological variables were determined by using MANOVA/ANOVA and LSD Post Hoc test. The results indicate that, in regards to the BMI, there are significant differences in morphological characteristics in eight-year-old girls. The highest values were observed in obese, then overweight, while the value for at least had normal weight girls.

Keywords: differences, elementary school, girls, morphological characteristic, girls, nutritional status.

Примљен: 06.03.2017.

Прихваћен: 31.10.2017.

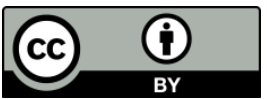

\footnotetext{
${ }^{1}$ mdjordjevic@vaspks.edu.rs, Preschool Teacher Training College, Kruševac

2 bokimitrovic976@gmail.com, Department for Police Education and Trainning, Ministry of Interior of the Republic of Serbia, Belgrade
} 